\title{
Low concentrations of the histone deacetylase inhibitor, depsipeptide, enhance the effects of gemcitabine and docetaxel in hormone refractory prostate cancer cells
}

\author{
MASATOSHI KANZAKI, HIDEAKI KAKINUMA, TERUAKI KUMAZAWA, TAKAMITSU INOUE, \\ MITSURU SAITO, SHINTAROU NARITA, TAKESHI YUASA, NORIHIKO TSUCHIYA and TOMONORI HABUCHI \\ Department of Urology, Akita University School of Medicine, Akita, Japan
}

Received November 15, 2006; Accepted December 21, 2006

\begin{abstract}
Histone deacetylase inhibitors (HDACis) have been developed as a new type of drug for cancer treatment. In this study, we examine the augmentation efficacy of depsipeptide (FK228) in combination with gemcitabine (GEM) or docetaxel (DOC) in vitro and in vivo against hormone refractory prostate cancer (HRPC). The antiproliferative effects, cell cycle distribution and apoptotic status were assessed in HRPC DU145 cells treated with these agents. The in vivo anti-tumor effects of the combination therapy with FK228 and GEM were further evaluated in the DU145 xenografts. FK228 induced a substantial acetylation of the histone proteins even at a low concentration of $\mathrm{IC}_{20}(0.56$ $\mathrm{ng} / \mathrm{ml}$ for $48 \mathrm{~h}$ treatment), while no effects on the cell cycle arrest and apoptosis induction were observed at the low concentration level. The pretreatment of cells with the $\mathrm{IC}_{20}$ dose of FK228 enhanced the cytotoxicity of both chemotherapeutic agents although the augmentation was more profoundly observed in GEM than DOC. The effects of the FK228 pretreatment were also observed in the in vivo experiment. The mean tumor doubling-time in the FK228 pretreatment combined with GEM was two times longer than that of the monotherapy with FK228 or GEM $(\mathrm{p}<0.001)$. These results show that pretreatment with low-dose FK228 enhances the chemosensitivity of DU145 tumors to GEM in vivo, suggesting the therapeutic potential of a new combination of HDACis and conventional chemotherapeutic agents. Further studies are required in order to assess the efficacy of this combination regimen in HRPCs in general.
\end{abstract}

Correspondence to: Professor Tomonori Habuchi, Department of Urology, Akita University School of Medicine, 1-1-1 Hondo, Akita City, Akita 010-8543, Japan

E-mail: thabuchi@doc.med.akita-u.ac.jp

Key words: histone deacetylase inhibitor, depsipeptide, prostate cancer, gemcitabine, docetaxel

\section{Introduction}

Prostate cancer is the second leading cause of cancer-related deaths in men in the United States (1) and the seventh in Japan (2). Men with newly diagnosed advanced prostate cancer respond well to surgical or medical castration (3). However, in virtually all patients the tumor ultimately becomes hormone refractory 18 to 24 months after castration $(3,4)$. Despite the emergence of new regimens using chemotherapeutic agents such as docetaxel (DOC), paclitaxel and gemictabine (GEM), the outcome of hormone refractory prostate cancer (HRPC) is still dismal $(5,6)$. Furthermore, although GEM has demonstrated substantial clinical activity against several common cancers, the clinical efficacy on prostate cancer is less than that observed in other cancers. Therefore, novel modalities for HRPC have been explored extensively both in laboratory and clinical settings (7).

The acetylation of the histone proteins neutralizes the positive charge on the lysine residues at their amino-terminal tails and causes a dynamic change in the chromatin structure. This change leads to the loosening of the histone-DNA contacts, and allows transcription factors to assemble and control gene expression $(8,9)$. In normal cells, a dynamic equilibrium exists between histone acetyltransferase (HAT) and histone deacetylase (HDAC) activities (10). On the contrary, an imbalance in both HAT and HDAC activities has been found in many human cancers including stomach (11), lung (12), breast (13) and HRPCs (14). Several studies have shown that the abnormal HAT inactivation could lead to the aberrant expression of growth regulators and could be associated with tumorigenesis (15). It has been demonstrated that the HDAC inhibition induces tumor cell differentiation, apoptosis, and/or growth arrest, depending on the experimental system (16). Therefore, HATs and HDACs could be potential targets in cancer therapy and HDAC inhibitors (HDACis) have already been developed and studied (15). HDACis, such as trichostatin A (TSA), suberoylanilide hydroxamic acid (SAHA), phenyl butylate, valproic acid, Cl-994, and MS-275, have been shown to have anti-tumor effects in several in vitro and in vivo models (17). Depsipeptide (FK228), classified as a cyclic peptide, has anti-tumor effects even at nanomolar concentrations in vitro $(18,19)$. In addition, FK228 exists in 
its stable and inactive form in media or sera and is converted to its active form in tumor cells by the intracellular reducing activity (20). Thus, FK228 functions as a prodrug and is one of the most promising HDACis.

Recent studies have raised the possibility that some HDACis can alter the sensitivity to chemotherapeutic agents in vitro (21), thus functioning as biomodulaters. Clinically, valproic acid, an HDACi utilized as a biomodulater, improves the efficiency of all-trans retinoic acid for acute myeloid leukemia (22). In this study, we examined the possibility of the combination treatment with FK228 and chemotherapeutic agents, as prostate cancer is usually resistant to conventional chemotherapeutic agents.

In the present study, we explored the in vitro and in vivo efficacy of the combination therapy with FK228 and the chemotherapeutic agents, GEM and DOC, using DU145 cells as a HRPC model.

\section{Materials and methods}

Cell culture. Androgen independent human prostate cancer cell line DU145 cells (American Type Culture Collection, Rockville, MD, USA) were grown in RPMI-1640 medium containing 10\% fetal bovine serum (Life Technologies, Gaithersburg, MD, USA). The cells were routinely cultured in a humidified incubator at $37^{\circ} \mathrm{C}$ with $5 \% \mathrm{CO}_{2}$ and harvested by $0.25 \%$ trypsin. The cells were confirmed to be free of mycoplasma and used in the log-phase of growth. All in vitro experiments were performed in triplicate.

Drugs. FK228, kindly provided by Dr W. McCulloch (Gloucester Pharmaceuticals, Cambridge, MA, USA), was dissolved in ethanol and diluted at specified concentrations with medium. For in vivo studies, FK228 was diluted at specified concentrations with $10 \%$ polyoxyethylated hydrogenated caster oil (HCO60) in physiological saline. GEM (Gemzar; Eli Lilly Japan, Kobe, Japan) and DOC (Toronto Research Chemicals, North York, Ontario, Canada) were dissolved in saline and ethanol, respectively.

3-(4,5-dimethylthiazol-2-yl)-2,5-diphenyltetrazolium bromide (MTT) cell proliferation assay. The cells were incubated in 96-well micro-plates and the number of viable cells was determined by MTT assay (Promega, Madison, WI, USA) at the end of each incubation. Briefly, 3,000 cells/well in $200 \mu 1$ cultured medium were incubated in the presence or absence of drugs. Ten microliters Cell Titer 96 Aqueous One Solution (Promega) were added to each well at the end of the incubation. After a 60 -min incubation at $37^{\circ} \mathrm{C}$, the absorbance was measured at $450 \mathrm{~nm}$ using a reference at $600 \mathrm{~nm}$ by the micro-plate reader (Bio-Rad Laboratories, Hercules, CA, USA). The concentration of the percentage growth inhibition value $\left(\mathrm{IC}_{\%}\right)$ was determined.

Histochemical staining for acetylated histone H3. The acetylated histone $\mathrm{H} 3$ protein expression in the DU145 cells was assessed by the immunohistochemical staining of cultured cells. Briefly, $5 \times 10^{4}$ cells were incubated with medium containing the $\mathrm{IC}_{20}(0.56 \mathrm{ng} / \mathrm{ml})$ and $\mathrm{IC}_{50}(1.1 \mathrm{ng} / \mathrm{ml})$ dose of FK228 for $48 \mathrm{~h}$ on two chamber glass slides (Becton
Dickinson, Bedford, MA, USA). The slides were fixed in $95 \%$ ethanol $/ 5 \%$ acetic acid for $1 \mathrm{~min}$ at room temperature. After fixation, the slides were washed twice with PBS for $15 \mathrm{~min}$, blocked in $8 \%$ BSA in PBS for $1 \mathrm{~h}$ at room temperature, and washed for $15 \mathrm{~min}$ in PBS before incubating for $3 \mathrm{~h}$ at room temperature with $5 \mu \mathrm{g} / \mathrm{ml}$ anti-acetylated histone $\mathrm{H} 3$ (Upstate Biotechnology, Lake Placid, NY, USA) in 1\% BSA in PBS. Subsequently, the cells were washed twice with PBS for 5 min at room temperature and then stained with a 1:100 dilution of goat anti-rabbit IgG fluorescent conjugated secondary antibody (Vector Laboratories, Burlingame, CA, USA) in 1\% BSA in PBS and then incubated for $1 \mathrm{~h}$ at room temperature. After staining, the slides were washed three times with PBS for $15 \mathrm{~min}$ and then the cells were examined under a fluorescent microscope.

Cell cycle analysis by flow cytometry. Flow cytometric analyses were performed to assess the effect of FK228 on the cell cycle of the DU145 cells. Briefly, $5 \times 10^{5}$ cells were incubated in medium with or without FK228 at different concentrations. The cells were harvested after a 48-h incubation and stained with propidium iodide using the CycleTEST ${ }^{\text {тм }}$ PLUS DNA reagent kit (Becton Dickinson). Flow cytometric analyses were performed on a flurorescent-activated cell sorter voltage flow byometer. Data acquisition and analyses were performed using CELLQuest software (Becton Dickinson). For each sample, 10,000 events were recorded.

The terminal deoxynucleotidyl transferase (TdT)-mediated dUTP nick end-labeling (TUNEL) staining. The presence of apoptotic cell death was evaluated by the TUNEL assay. Briefly, $5 \times 10^{4}$ cells $/ \mathrm{ml}$ were incubated in the presence or absence of FK228 for $48 \mathrm{~h}$ on two chamber slides. The TUNEL assay was performed using the ApopTag Peroxidase In situ Apoptosis Detection Kit (Chemicon International, Temecula, CA, USA). A dark brown color indicates DNA breaks that developed after incubation with 3-3'-diamonobenzidine tetrachloride (DAB) and hydrogen peroxide. The apoptotic index was defined as the percentage of positive cells in 1,000 cells from three arbitary microscopic fields (x400).

In vivo tumor xenograft model. Male BALB/c nu/nu mice at 6 weeks of age were purchased from Nippon SLC (Tokyo, Japan) and maintained in our facility under specific pathogenfree conditions with access to mouse chow and water ad libitum. All experiments were performed in accordance with the guidelines for animal manipulation of the Akita University School of Medicine. Xenografts derived from the DU145 cells were established by the subcutaneous injection of $2 \times 10^{6}$ cells suspended in $0.25 \mathrm{ml}$ RPMI-1640 medium and $0.25 \mathrm{ml}$ Matrigel Basement Membrane Matrix (Becton Dickinson) into the right hind leg. When the estimated tumor volume reached 200-300 $\mathrm{mm}^{3}$, the mice were divided into 4 experimental groups: Control $(n=10)$, FK228 alone $(n=10)$, GEM alone $(n=10)$, and FK228 plus GEM $(n=10)$. FK228 $(2.4 \mathrm{mg} / \mathrm{kg}$ ) was injected into the peritoneum three times on days 1, 5, and 9 and GEM (200 mg/kg, i.p.) was given once on day 9 . In the control mice, the agents were replaced with $10 \%$ HCO60 or physiological saline. To obtain a tumor growth curve, the perpendicular diameter of each tumor was 


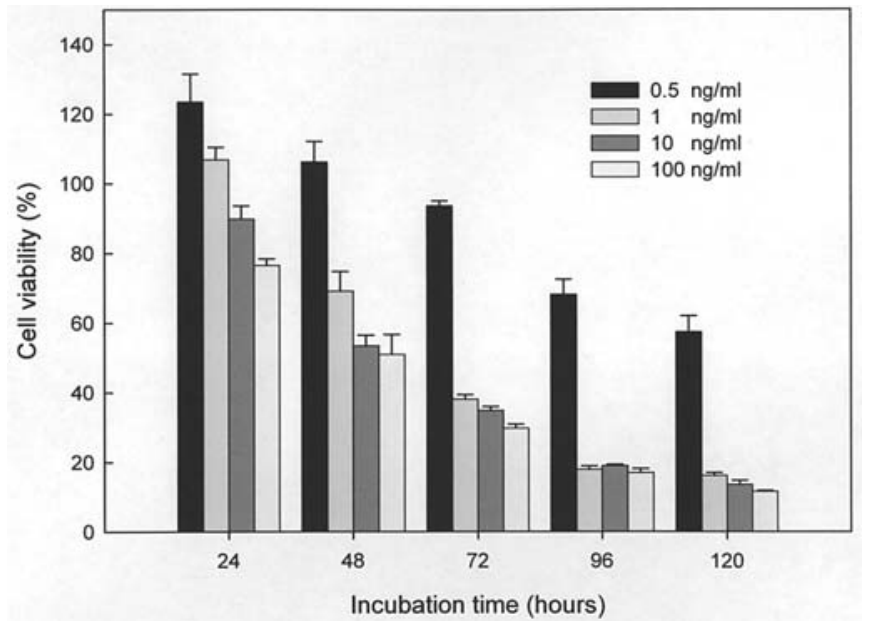

Figure 1. The growth inhibitory effects of depsipeptide (FK228) on DU145 cells. The bars show the percentage cell viability after 24 to $120 \mathrm{~h}$ incubation with FK228 at specified concentrations $(0.5-100 \mathrm{ng} / \mathrm{ml})$ as a reference to the non-treated cells. The $\mathrm{IC}_{20}$ and $\mathrm{IC}_{50}$ values for $48 \mathrm{~h}$-exposure were estimated as $0.56 \mathrm{ng} / \mathrm{ml}$ and $1.10 \mathrm{ng} / \mathrm{ml}$, respectively. The error bars represent the standard error (S.E.) calculated from triplicated samples.

measured with vernier calipers every 7 days for 14 weeks, and volumes were calculated using the formula $(\mathrm{LxWxW}) / 2$. The tumor doubling-time (Dt) was calculated using the tumor volumes at 4,8 , and 12 weeks. It was calculated according to the formula $\mathrm{T}=\log 2 \mathrm{xt} / \log$ (final tumor volume) - $\log$ (initial tumor volume), where $t$ is the time (days) from the initial tumor volume to the final tumor volume.

Statistical analysis. Statistical significance was evaluated by the Student's t-test or a two-way ANOVA using SPSS (SPSS Inc, Chicago, IL, USA).

\section{Results}

The anti-proliferative effect of FK228 on DU145 cells with or without GEM or DOC. We first assessed the growth inhibitory effect by treating the DU145 cells with $0.5,1,10$ and $100 \mathrm{ng} / \mathrm{ml} \mathrm{FK} 228$ for 24, 48, 72, 96 and $120 \mathrm{~h}$ (Fig. 1). FK228 inhibited the proliferation of the DU145 cells in a time- and dose-dependent manner (Fig. 1). The $\mathrm{IC}_{20}$ and $\mathrm{IC}_{50}$ values for the 48 -h exposure were defined as $0.56 \mathrm{ng} / \mathrm{ml}$ and $1.10 \mathrm{ng} / \mathrm{ml}$, respectively. To test for the sensitizing or augmentative effect of FK228 with the cytotoxic anticancer agents, the cells were pretreated with the $\mathrm{IC}_{20}$ dose of $\mathrm{FK} 228$ for $48 \mathrm{~h}$ before treating with GEM $(10 \mathrm{ng} / \mathrm{ml})$ or DOC $(100 \mathrm{ng} / \mathrm{ml})$, in addition to the single treatment with these anticancer agents. Although the augmentative effect of the pretreatment of lowdose FK228 for chemosensitivity was evident in both agents, it was less clear for DOC (Fig. 2A and B). In the case of GEM, the growth inhibition rate increased 2.3-12.3-fold when the cells were pretreated with FK228 compared with the GEM treatment alone $[2.6 \%$ vs $32.1 \%$ at $24 \mathrm{~h}(\mathrm{p}<0.001), 13.9 \%$ vs $34.3 \%$ at $48 \mathrm{~h}(\mathrm{p}=0.002), 14.5 \%$ vs $32.8 \%$ at $72 \mathrm{~h}(\mathrm{p}=0.002)$, and $16.8 \%$ vs $50.1 \%$ at $96 \mathrm{~h}(\mathrm{p}<0.001)$, respectively.] (Fig. 2A). The augmentation of growth inhibition by pretreatment with FK228 was also observed in the case of DOC. However, the extent of the cytotoxicity of DOC in the presence of FK228 was $<2.4$-fold compared with the DOC treatment alone $(\mathrm{p}<0.04)$ (Fig. 2B). No augmentation was observed when the cells were simultaneously exposed to FK228 and the chemotherapeutic agents, indicating the importance of pretreatment with a low dose of FK228 ( $\mathrm{p}=0.48, \mathrm{p}=0.86$ ) (Fig. 2C and D).

The expression of histone protein by FK228. Since growth inhibitory augmentation was observed even in the presence of low-dose $\left(\mathrm{IC}_{20}\right)$ pretreatment with $\mathrm{FK} 228$, we then evaluated the extent of histone acetylation by treating with the $\mathrm{IC}_{20}$ dose of FK228 using immunohistochemical staining with anti-acetylated histone $\mathrm{H} 3$. A marked increase in the acetylated histone protein $\mathrm{H} 3$ was visualized by intense nuclear staining in the DU145 cells treated with FK228 for 24 h (Fig. 3). Despite its minimal cytotoxicity, the $\mathrm{IC}_{20}$ dose of FK228 induced a marked acetylation of the histone protein.

The effects of FK228 on the cell cycle of DU145 cells. Previous studies have shown that FK228 mainly causes $\mathrm{G}_{1}$ cell cycle arrest at relatively higher dose levels (e.g.: 1-100 ng/ml) in several cell lines (23). We tried to confirm this observation and further evaluated the cell cycle fraction in a low-dose setting. In accordance with previous reports (23), the $\mathrm{IC}_{50}$ dose of FK228 (1.10 ng/ml for 48-h exposure) mainly induced $\mathrm{G}_{1}$ cell cycle arrest with a slight increase in the $\mathrm{G}_{2} / \mathrm{M}$ fraction and a decrease in the S phase fraction in DU145 cells (Fig. 4A and B). However, when the cells were treated with the $\mathrm{IC}_{20}$ dose of FK228 (0.56 ng/ml for 48-h exposure), no significant change in the cell cycle population was observed although an increase in the $G_{1}$ phase fraction and a slight decrease in the $S$ phase fraction were observed (control vs FK228, p<0.001) (Fig. 4A and B).

Apoptosis induction by FK228. Next, the induction of apoptosis after incubation with FK228 at two dose levels $\left(\mathrm{IC}_{20}\right.$ and $\left.\mathrm{IC}_{50}\right)$ was examined by the TUNEL assay. The assay indicated the induction of apoptosis of the DU145 cells by the FK228 treatment (Fig. 5A). The apoptotic index in the cells treated with the $\mathrm{IC}_{50}$ dose of FK228 $(1.1 \mathrm{ng} / \mathrm{ml}$ for $48-\mathrm{h}$ exposure) increased $>6 \mathrm{x}$ over the control $(34.6 \%$ vs $5 \%$, $\mathrm{p}<0.001$ ), suggesting a strong apoptotic induction. However, the apoptotic induction by the $\mathrm{IC}_{20}$ dose of FK228 was marginal (9.9\% vs 5\%, p=0.001) (Fig. 5B).

The anti-tumor effects of FK228 and GEM on DU145 xenografts. Finally, in order to evaluate the augmentative effect of FK228 in vivo, we tested the effect of FK228 alone, GEM alone, or their combination using DU145 xenografts. Although the anti-tumor effect of monotherapy (FK228 or GEM) was observed to a certain extent, that of combination therapy (FK228 + GEM) was the most prominent (Fig. 6A). Tumor growth was reduced $\sim 50 \%$ at 12 weeks compared to the control $\left(1,321 \pm 271 \mathrm{~mm}^{3}\right.$ vs $\left.3,936 \pm 581 \mathrm{~mm}^{3}\right)$ (Fig. 6A). The Dt in the combination therapy group was two times longer than that of the monotherapy groups (FK228 or GEM). These differences were statistically significant $(70.2 \pm 14.1$ vs $30.8 \pm 3.6$, $33.6 \pm 4.6$ days, $\mathrm{p}<0.005$ ) (Fig. 6B). We did not detect any harmful effects in the experimental groups. The body weights of the mice did not differ significantly (data not shown). 


\section{A}

\section{B}
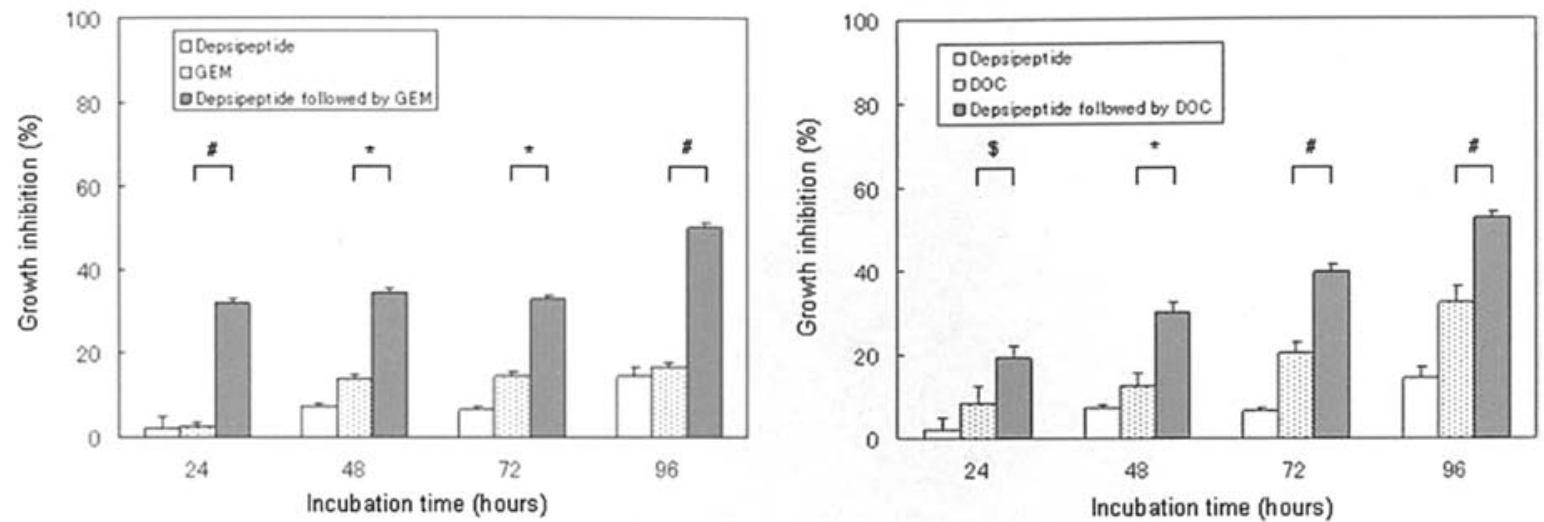

C

D
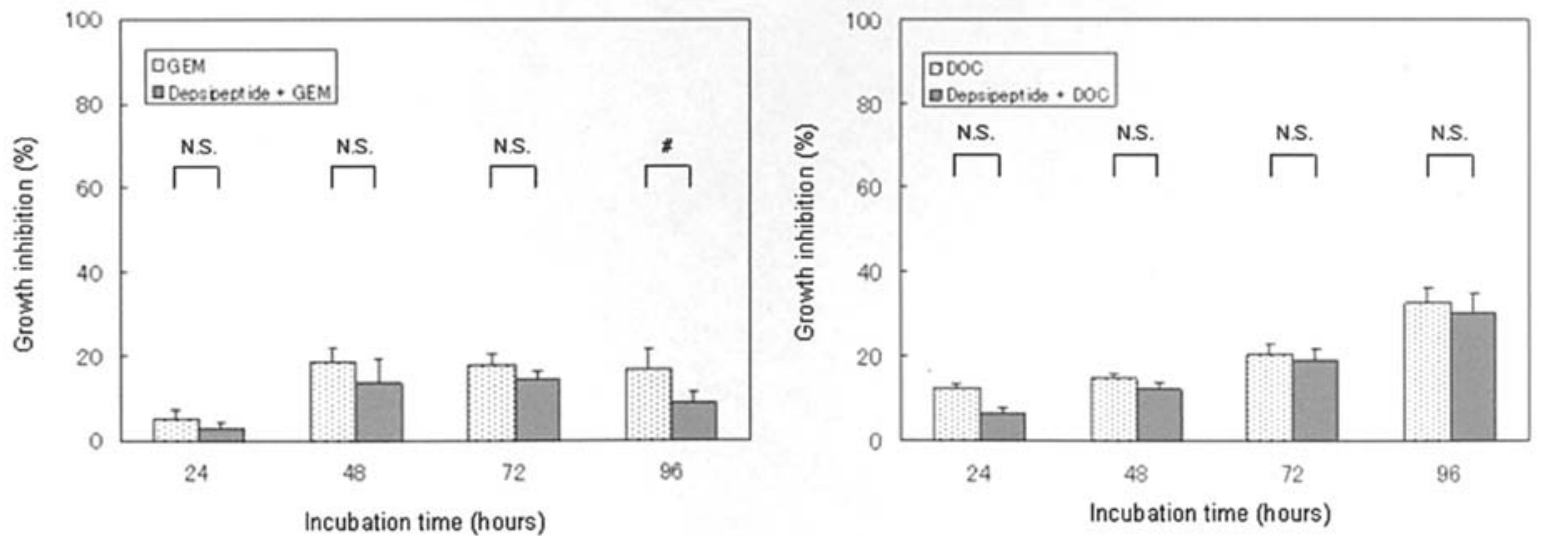

Figure 2. The augmentation effects of depsipeptide (FK228) combined with or without gemcitabine (GEM) or docetaxel (DOC). Pretreatment with FK228 enhanced the chemosensitivity of the DU145 cells to GEM (A) and DOC (B). A marked increase in the cytotoxicity of GEM was indicated, showing higher growth inhibition in the cells pretreated with FK228 as compared to those treated with GEM alone. No augmentative effect was observed in the cells simultaneously exposed to FK228 and GEM or DOC (C and D). N.S., not significant; ${ }^{\$} \mathrm{p}<0.05 ;{ }^{*} \mathrm{p}<0.01 ;{ }^{*} \mathrm{p}<0.001$ (combination treatment of FK228 with GEM or DOC vs GEM or DOC treatment alone).
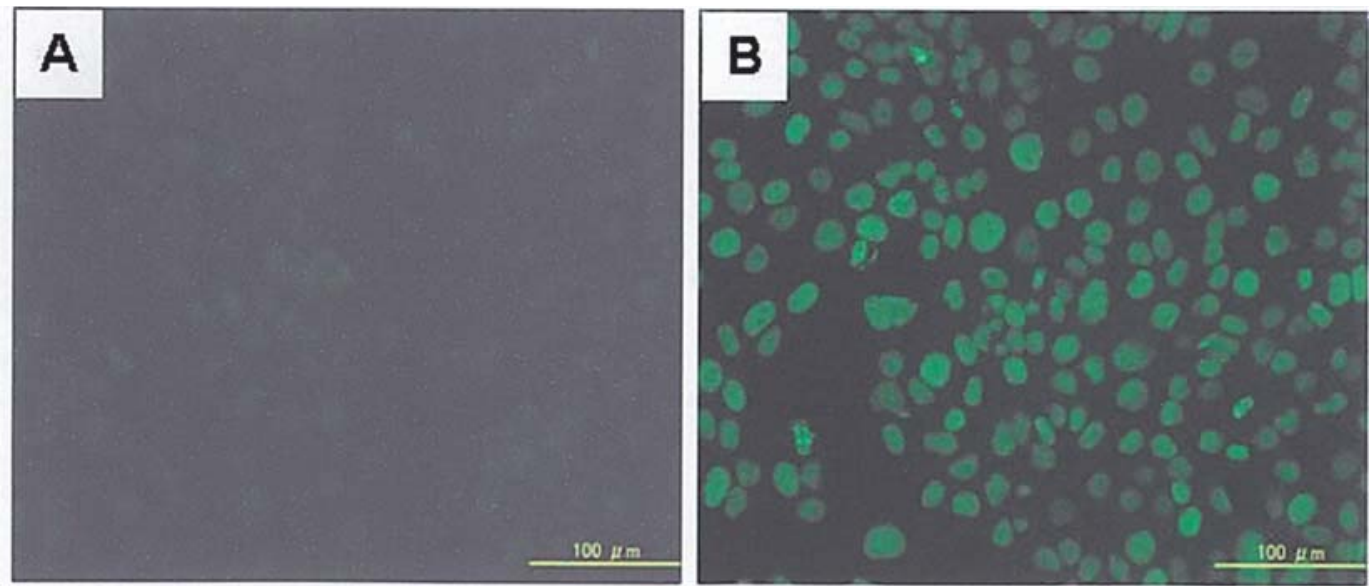

Figure 3. The expression of the histone H3 protein by depsipeptide (FK228) in the DU145 cells. The slides were stained with an FITC-labeled antibody against the acetylated histone $\mathrm{H} 3$ protein. Exposure times for all photographs were identical. The administration of a low dose of FK228 (0.56 ng/ml) for $48 \mathrm{~h}$ led to a marked increase in the acetylated histone protein in the nuclei. (A) Control and (B) $0.56 \mathrm{ng} / \mathrm{ml} \mathrm{FK228.}$ 

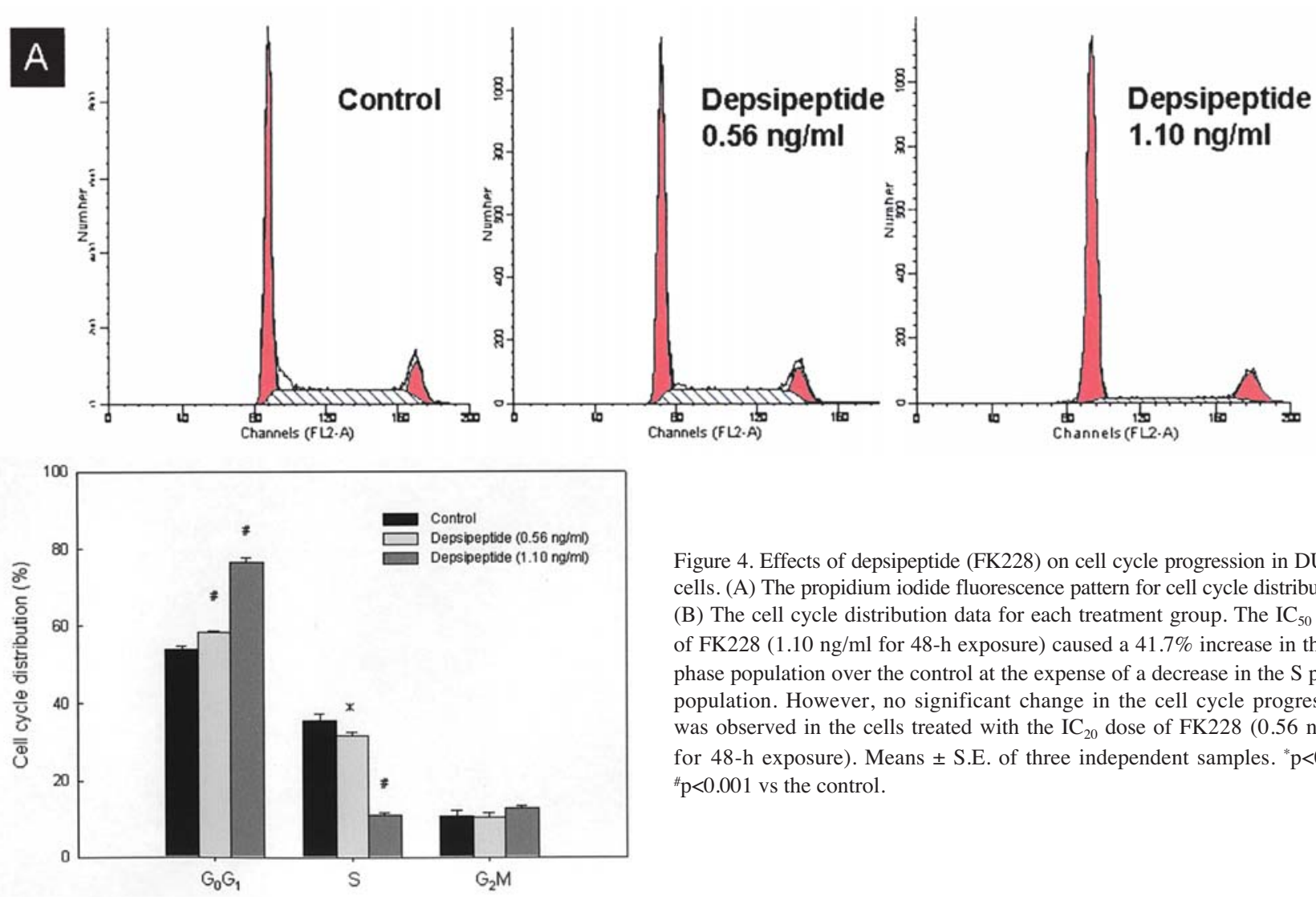

Figure 4. Effects of depsipeptide (FK228) on cell cycle progression in DU145 cells. (A) The propidium iodide fluorescence pattern for cell cycle distribution. (B) The cell cycle distribution data for each treatment group. The $\mathrm{IC}_{50}$ dose of FK228 (1.10 ng/ml for 48-h exposure) caused a $41.7 \%$ increase in the $\mathrm{G}_{1}$ phase population over the control at the expense of a decrease in the $\mathrm{S}$ phase population. However, no significant change in the cell cycle progression was observed in the cells treated with the $\mathrm{IC}_{20}$ dose of FK228 $(0.56 \mathrm{ng} / \mathrm{ml}$ for 48 - $\mathrm{h}$ exposure). Means \pm S.E. of three independent samples. ${ }^{*} \mathrm{p}<0.01$, ${ }^{\#} \mathrm{p}<0.001$ vs the control.
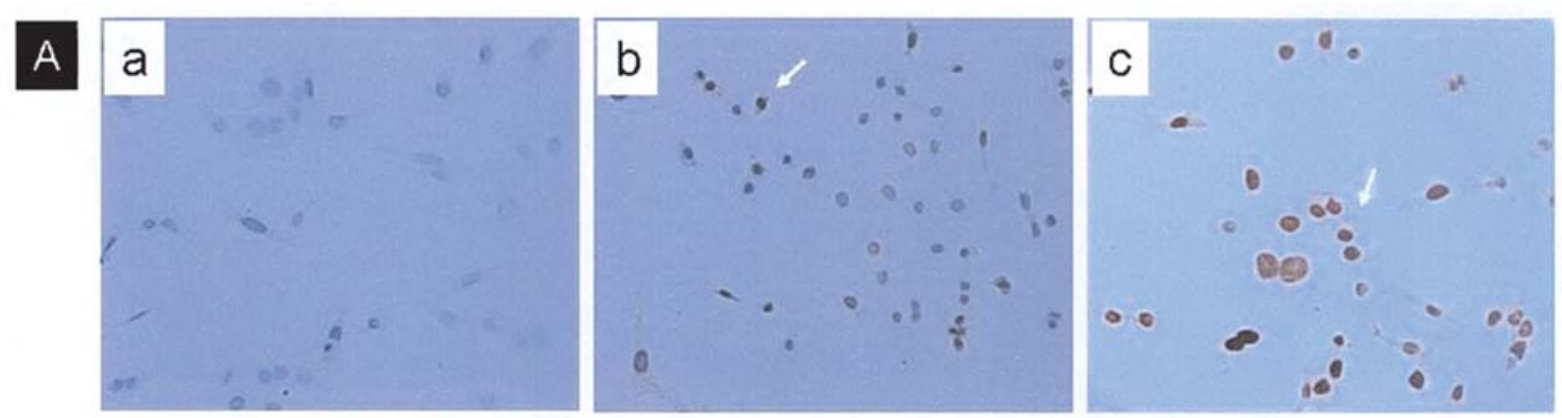

B

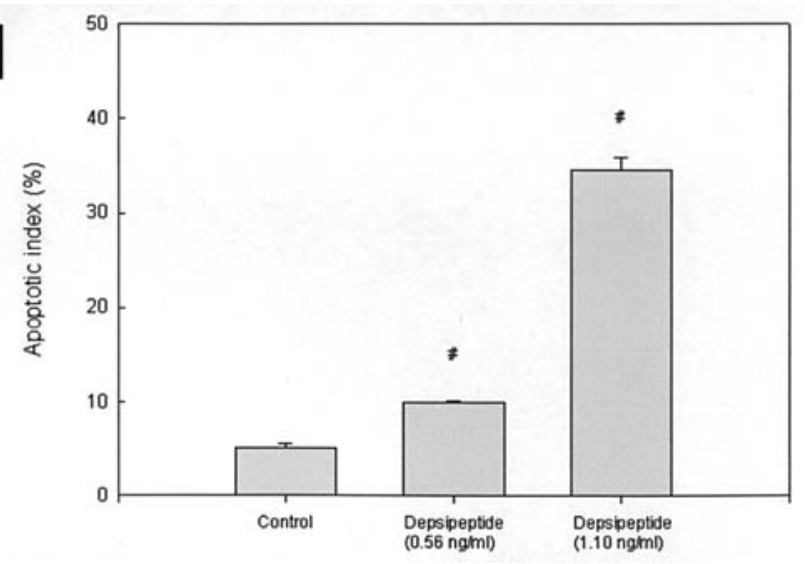

Figure 5. Apoptosis induction by depsipeptide (FK228). (A) The induction of apoptosis by FK228 was indicated by TUNEL-positive cells. Affected cells showed dark brown staining in the nuclei (arrow heads). The cells were treated with FK228 at specified concentrations. a) Control, b) $0.56 \mathrm{ng} / \mathrm{ml}$, c) $1.1 \mathrm{ng} / \mathrm{ml}$. (B) The apoptotic index was defined as the percentage of positive cells in 1,000 cells from three arbitrary microscopic fields (x400). The induction of apoptosis by FK228 was indicated, showing the increased mean apoptotic index in the cells treated with FK228 as compared to the control. ${ }^{*} \mathrm{p}<0.001$ vs the control.

\section{Discussion}

In the present study, pretreatment with a low dose of FK228 enhanced the cytotoxicity of GEM and DOC in vitro, showing a 2.3-12.3-fold and 1.6-2.4-fold growth inhibition compared to the monotherapy treatment (Fig. 2A and B). It should be

noted that, no augmentation was observed in the cells simultaneously exposed to FK228 and the anticancer drugs (Fig. 2C and D). Similarly, Kim et al (21) reported that treatment with small doses of trichostatin A and SAHA increased the sensitivity to etoposide and cisplatin. Furthermore, in accordance with our findings, they also found that the 
A
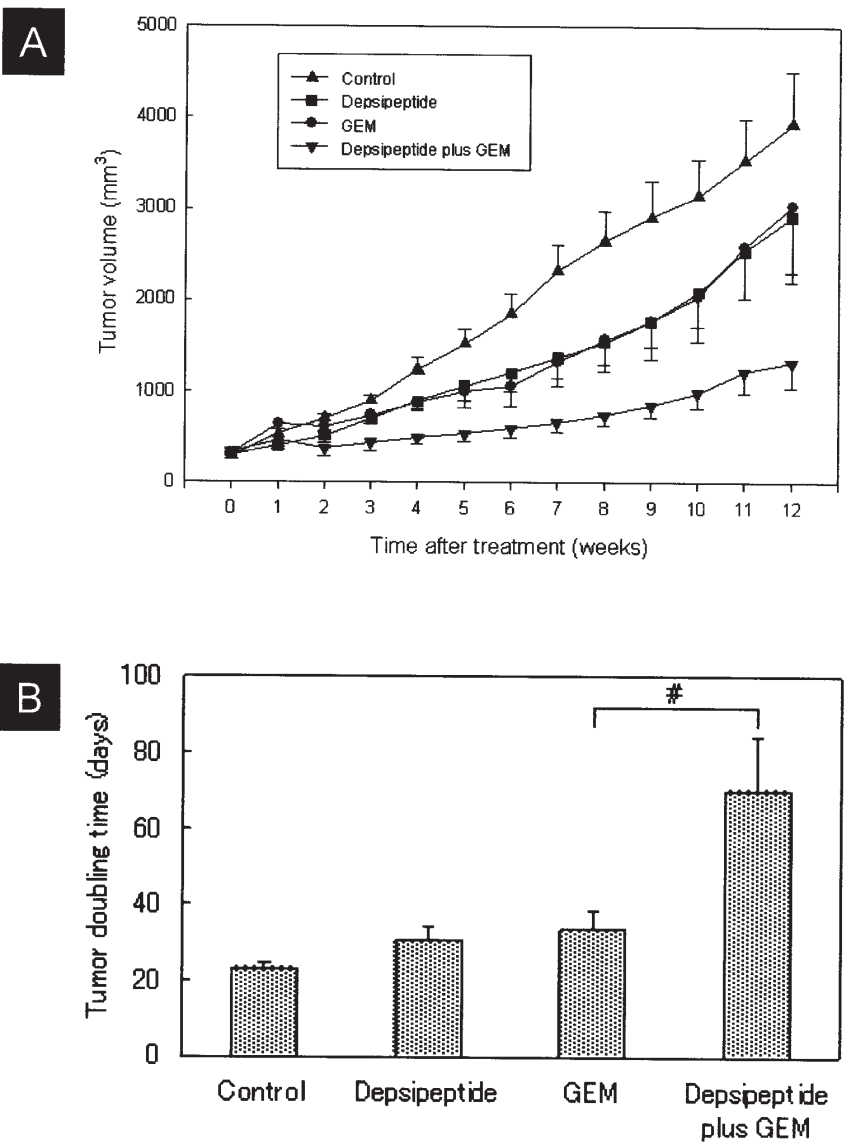

Figure 6. (A) The tumor growth curves of DU145 xenografts in mice. The mean tumor sizes and S.E. in each group were plotted [ $[\mathbf{\Lambda}$, vehicle; $\mathbf{\bullet}$, depsipeptide (FK228); •, gemcitabine (GEM); v, FK228 plus GEM]. Maximal tumor growth inhibition was observed with the combination therapy with FK228 and GEM. (B) The tumor volume doubling-time in each group. The tumor doubling-time with the combination therapy was two times longer than that with monotherapy (FK228 or GEM). The difference was statistically significant $\left({ }^{\#} \mathrm{p}<0.001\right)$.

augmentation of the anticancer drugs by HDACis was observed only when the cells were pretreated with the HDACis prior to the etoposide and cisplatin administration (21). They observed no augmentation using fluorouracil and cyclophosphamide (21) and there was a substantial difference in the extent of the augmentation by FK228 between DOC and GEM in this study, suggesting that the augmentative effect associated with HDACis varies substantially according to the anticancer agents used.

In our study, the low-dose administration ( $1 \mathrm{nM})$ of FK228 for 48 h caused substantial histone acetylation in vitro (Fig. 3) as already reported by others (18), while a low dose of FK228 did not induce cell cycle arrest or apoptosis (Figs. 4 and 5). The results support the findings of Sandor et al $(23,24)$ who suggested that a high dose of FK228 (2 nM or more) is required to induce cell cycle arrest. Zhu et al also observed (25) that a high dose of FK228 $(50 \mathrm{nM})$ is required to induce substantial apoptosis.

These data suggest that the augmentation of anticancer drugs by FK228 is not due to the synergistic interaction of the cytotoxic effect of FK228 and anticancer drugs but is rather due to the observed histone hyperacetylation (Fig. 3). Previously, it has been reported that the pretreatment of drug- resistant cancer cells with the HDACi, trichostatin A, increases topoisometase II inhibitor cytotoxicity, possibly due to the interaction of topoisometase II and HDAC (26). However, our data and those of others suggest that other mechanisms are involved in the augmentation of the cytotoxic effects of anticancer drugs by pretreatment with HDACis (21). Kim et al hypothesized that the more open state of the chromatin structure by histone hyperacetylation can allow the anticancer drugs targeting the DNA or the enzymes acting on the DNA to access the DNA more efficiently (21). However, GEM and DOC do not directly target the DNA. In contrast, FK228 can alter the expression pattern of certain genes that may be involved in drug metabolism, sensitivity and genotoxic response. Furthermore, the augmentative effect by HDACis can enhance the function of p53 or other pro-apoptotic proteins through acetylation. However, the augmentative effect was only observed when cells were pretreated with HDACis and not with the simultaneous or reverse order administration. Therefore, the augmentative effect of the low-dose pretreatment with FK228 could be caused by other undefined mechanisms. Further investigation into the molecular mechanisms underlying the FK228 sensitization to anticancer drugs is required.

Kim et al also discovered the augmentative effect of the pretreatment of low-dose HDACis with anticancer drugs in glioblastoma and breast cancer cells, and we also discovered a similar augmentative effect in T24 bladder cancer cells with FK228 and GEM (data not shown). Thus, it is expected that the sensitization to anticancer drugs by the low-dose pretreatment with HDACis prior to anticancer drug administration can be applied to a variety of tumors.

It is still unclear whether this enhancement by HDACis functions effectively as a biomodulater in vivo. Sasakawa et al and Ito et al $(27,28)$ reported that treatment with FK228 alone has antitumor effects for prostate cancer and sarcoma xenografts. However, the dose-dependency of FK228's antitumor effect which was observed in vitro was not observed in vivo $(27,28)$. Although much higher serum levels of FK228 (920 nM and $92 \mathrm{nM}$ of free FK228 concentration) were used in clinical settings $(22,29-31)$, FK228 monotherapy is limited as the high dose of FK228 required to obtain a clinical response could be toxic. Therefore, it is important to explore the possible augmentative effects of FK228 on conventional anticancer drugs in an in vivo human tumor xenograft model in addition to in vitro observation. In this study, we evaluated the FK228/GEM combination therapy in a human tumor xenograft model in order to reduce the dose of FK228 and GEM. We focused on GEM as a therapeutic partner for FK228 in vivo as GEM has a better synergic effect with FK228 than DOC in vitro.

In the present study, it was observed that during the 12week treatment period the anti-tumor effect of combination therapy (FK228 plus GEM) was more robust than monotherapy (FK228 or GEM alone) (Fig. 6A), resulting in the prolongation of the tumor doubling-time in the combination therapy (Fig. 6B). Although there may be a great difference in the metabolism and distribution of FK228 between humans and animals, the administered dose of $2.4 \mathrm{mg} / \mathrm{kg}$ was comparable to the dose used clinically $\left(1-24.9 \mathrm{mg} / \mathrm{m}^{2}\right)$. Although we did not measure the serum levels of FK228 in animals and did 
not evaluate the acetylated histones in the DU145 xenografts and normal tissues in mice after the FK228 administration, Sandor et al observed significant histone acetylation in mononuclear cells after FK228 administration in patients (31). In the present study, we examined the body weight of the mice and mortality and no harmful effects were observed even in the mice that were treated with a combination of FK228 and GEM. Therefore, the results provide preclinical evidence for the consideration of HDACi FK228 in combination therapy with conventional anticancer drugs while reducing the toxicity associated with these drugs. To our knowledge, this is the first study reporting the enhanced cytotoxicity of anticancer drugs to HRPC cells by pretreatment with the HDACi FK228 in an in vivo model. The defect of the study was that we only examined a DU145 cell line as a HRPC model. Therefore, further studies are mandatory in order to assess whether the combination therapy with low-dose FK228 pretreatment and chemotherapeutic agents is also effective in HRPCs in general.

\section{References}

1. Jemal A, Murray T, Ward E, Samuels A, Tiwari RC, Ghafoor A, Feuer EJ and Thun MJ: Cancer statistics. CA Cancer J Clin 55: 10-30, 2005.

2. Wakai K: Descriptive epidemiology of prostate cancer in Japan and Western countries. Nippon Rinsho 63: 207-212, 2005.

3. Crawford ED, Eisenberger MA, McLeod DG, Spaulding JT, Benson R, Dorr FA, Blumenstein BA, Davis MA and Goodman PJ: A controlled trial of leuprolide with and without flutamide in prostatic carcinoma. N Engl J Med 321: 419-424, 1989.

4. Eisenberger MA, Blumenstein BA, Crawford ED, Miller G, McLeod DG, Loehrer PJ, Wilding G, Sears K, Culkin DJ, Thompson IM Jr, Bueschen AJ and Lowe BA: Bilateral orchiectomy with or without flutamide for metastatic prostate cancer. N Engl J Med 339: 1036-1042, 1998.

5. Petrylak DP, Tangen CM, Hussain MH, Lara PN Jr, Jones JA, Taplin ME, Burch PA, Berry D, Moinpour C, Kohli M, Benson MC, Small EJ, Raghavan D and Crawford ED: Docetaxel and estramustine compared with mitoxantrone and prednisone for advanced refractory prostate cancer. N Engl J Med 351: 1513-1520, 2004.

6. Tannock IF, de Wit R, Berry WR, Horti J, Pluzanska A, Chi KN, Oudard S, Theodore C, James ND, Turesson I, Rosenthal MA and Eisenberger MA: Docetaxel plus prednisone or mitoxantrone plus prednisone for advanced prostate cancer. N Engl J Med 351: 1502-1512, 2004.

7. Armstrong AJ and Carducci MA: Chemotherapy for advanced prostate cancer: results of new clinical trials and future studies. Curr Oncol Rep 7: 220-227, 2005.

8. Grunstein M: Histone acetylation in chromatin structure and transcription: Nature 389: 349-352, 1997.

9. Turner BM: Decoding the nucleosome. Cell 75: 5-8, 1993.

10. Emiliani S, Fischle W, Van Lint C, Al-Abed Y and Verdin E: Characterization of a human RPD3 ortholog, HDAC3. Proc Natl Acad Sci USA 95: 2795-2800, 1998.

11. Choi JH, Kwon HJ, Yoon BI, Kim JH, Han SU, Joo HJ and Kim DY: Expression profile of histone deacetylase 1 in gastric cancer tissues. Jpn J Cancer Res 92: 1300-1304, 2001.

12. Osada H, Tatematsu Y, Saito H, Yatabe Y, Mitsudomi T and Takahashi T: Reduced expression of class II histone deacetylase genes is associated with poor prognosis in lung cancer patients. Int J Cancer 112: 26-32, 2004.

13. Zhang Z, Yamashita H, Toyama T, Sugiura H, Omoto Y, Ando Y, Mita K, Hamaguchi M, Hayashi S and Iwase H: HDAC6 expression is correlated with better survival in breast cancer. Clin Cancer Res 10: 6962-6968, 2004.

14. Halkidou K, Gaughan L, Cook S, Leung HY, Neal DE and Robson CN: Upregulation and nuclear recruitment of HDAC1 in hormone refractory prostate cancer. Prostate 59: 177-189, 2004.
15. Johnstone RW: Histone-deacetylase inhibitors: novel drugs for the treatment of cancer. Nat Rev Drug Discov 1: 287-299, 2002.

16. Minucci S and Pelicci PG: Histone deacetylase inhibitors and the promise of epigenetic (and more) treatments for cancer. Nat Rev Cancer 6: 38-51, 2006.

17. Marks PA and Dokmanovic M: Histone deacetylase inhibitors: discovery and development as anticancer agents. Expert Opin Investig Drugs 14: 1497-1511, 2005.

18. Kitazono M, Robey R, Zhan Z, Sarlis NJ, Skarulis MC, Aikou T, Bates S and Fojo T: Low concentrations of the histone deacetylase inhibitor, depsipeptide (FR901228), increase expression of the $\left.\left.\mathrm{Na}^{+}\right) / \mathrm{I}^{-}\right)$symporter and iodine accumulation in poorly differentiated thyroid carcinoma cells. J Clin Endocrinol Metab 86: 3430-3435, 2001.

19. Sasakawa Y, Naoe Y, Noto T, Inoue T, Sasakawa T, Matsuo M, Manda T and Mutoh S: Antitumor efficacy of FK228, a novel histone deacetylase inhibitor, depends on the effect on expression of angiogenesis factors. Biochem Pharmacol 66: 897-906, 2003.

20. Furumai R, Matsuyama A, Kobashi N, Lee KH, Nishiyama M, Nakajima H, Tanaka A, Komatsu Y, Nishino N, Yoshida M and Horinouchi S: FK228 (depsipeptide) as a natural prodrug that inhibits class I histone deacetylases. Cancer Res 62: 4916-4921, 2002.

21. Kim MS, Blake M, Baek JH, Kohlhagen G, Pommier Y and Carrier F: Inhibition of histone deacetylase increases cytotoxicity to anticancer drugs targeting DNA. Cancer Res 63: 7291-7300, 2003

22. Bug G, Ritter M, Wassmann B, Schoch C, Heinzel T, Schwarz K, Romanski A, Kramer OH, Kampfmann M, Hoelzer D, Neubauer A, Ruthardt M and Ottmann OG: Clinical trial of valproic acid and all-trans retinoic acid in patients with poorrisk acute myeloid leukemia. Cancer 104: 2717-2725, 2005.

23. Sandor V, Senderowicz A, Mertins S, Sackett D, Sausville E, Blagosklonny MV and Bates SE: P21-dependent g(1)arrest with downregulation of cyclin D1 and upregulation of cyclin $\mathrm{E}$ by the histone deacetylase inhibitor FR901228. Br J Cancer 83: 817-825, 2000.

24. Sandor V, Robbins AR, Robey R, Myers T, Sausville E, Bates SE and Sackett DL: FR901228 causes mitotic arrest but does not alter microtubule polymerization. Anticancer Drugs 11: 445-454, 2000.

25. Zhu WG, Lakshmanan RR, Beal MD and Otterson GA: DNA methyltransferase inhibition enhances apoptosis induced by histone deacetylase inhibitors. Cancer Res 61: 1327-1333, 2001.

26. Tsai SC, Valkov N, Yang WM, Gump J, Sullivan D and Seto E: Histone deacetylase interacts directly with DNA topoisomerase II. Nat Genet 26: 349-353, 2000.

27. Sasakawa Y, Naoe Y, Inoue T, Sasakawa T, Matsuo M, Manda T and Mutoh S: Effects of FK228, a novel histone deacetylase inhibitor, on tumor growth and expression of p21 and c-myc genes in vivo. Cancer Lett 195: 161-168, 2003.

28. Ito T, Ouchida M, Morimoto Y, Yoshida A, Jitsumori Y, Ozaki T, Sonobe H, Inoue H and Shimizu K: Significant growth suppression of synovial sarcomas by the histone deacetylase inhibitor FK228 in vitro and in vivo. Cancer Lett 224: 311-319, 2005.

29. Byrd JC, Marcucci G, Parthun MR, Xiao JJ, Klisovic RB, Moran M, Lin TS, Liu S, Sklenar AR, Davis ME, Lucas DM, Fischer B, Shank R, Tejaswi SL, Binkley P, Wright J, Chan KK and Grever MR: A phase 1 and pharmacodynamic study of depsipeptide (FK228) in chronic lymphocytic leukemia and acute myeloid leukemia. Blood 105: 959-967, 2005.

30. Piekarz RL, Robey R, Sandor V, Bakke S, Wilson WH, Dahmoush L, Kingma DM, Turner ML, Altemus R and Bates SE: Inhibitor of histone deacetylation, depsipeptide (FR901228), in the treatment of peripheral and cutaneous T-cell lymphoma: a case report. Blood 98: 2865-2868, 2001.

31. Sandor V, Bakke S, Robey RW, Kang MH, Blagosklonny MV, Bender J, Brooks R, Piekarz RL, Tucker E, Figg WD, Chan KK, Goldspiel B, Fojo AT, Balcerzak SP and Bates SE: Phase I trial of the histone deacetylase inhibitor, depsipeptide (FR901228, NSC 630176), in patients with refractory neoplasms. Clin Cancer Res 8: 718-728, 2002. 